\title{
PARTIAL PURIFICATION AND CATALYTIC PROPERTIES \\ OF A BIFUNCTIONAL ENZYME IN THE BIOSYNTHETIC PATHWAY \\ OF $\beta$-LACTAMS IN CEPHALOSPORIUM ACREMONIUM
}

\author{
A. Scheidegger, M. T. Küenzi and J. Nüesch \\ Research Laboratories of the Pharmaceutical Division of CIBA-GEIGY Limited, \\ $\mathrm{CH}-4002$ Basle, Switzerland
}

(Received for publication December 5, 1983)

\begin{abstract}
The catalytic properties of the partially purified deacetoxycephalosporin C (DAOC)synthetase and DAOC-hydroxylase from an industrial strain of Cephalosporium acremonium were studied. After mechanical breakage of the cells, purification was achieved by fractional $\left(\mathrm{NH}_{4}\right)_{2} \mathrm{SO}_{4}$ precipitation, gel chromatography on Sephadex G-75, ion exchange chromatography on DEAE-Trisacryl $\mathrm{M}$ and two isoelectric focusing steps. The two enzyme activities could not be separated. Indirect evidence was obtained from SDS-polyacrylamide gel electrophoresis of the purest fractions obtained by isoelectric focusing that the two reactions are catalyzed by a single enzyme with a molecular weight of $33,000 \pm 2,000$ and a pI of $4.6 \pm 0.1$. Both reactions require $\alpha$-ketoglutarate, $\mathrm{FeSO}_{4}$, ascorbate and $\mathrm{O}_{2}$, whereas additional ATP shows only a slight stimulation.
\end{abstract}

According to present knowledge, cephalosporin $\mathrm{C}$ biosynthesis by Cephalosporium acremonium starts with the formation of the tripeptide ${ }^{1)}$ and proceeds via cyclization ${ }^{2,3,4,5)}{ }^{2}$, epimerization ${ }^{6,7,8)}$ and ring expansion to deacetoxycephalosporin $\mathrm{C}(\mathrm{DAOC})^{5,0,10,11)}$. DAOC is hydroxylated to give deacetylcephalosporin $C(D A C)^{12,13)}$ from which cephalosporin $C$ is formed by acetylation ${ }^{14,15)}$.

During the industrial production of cephalosporin $\mathrm{C}$, the undesirable precursors penicillin $\mathrm{N}$, DAOC and DAC are released into the culture medium in varying amounts, depending on the cultivation conditions and mutants used. Since strains giving high yields of cephalosporin $\mathrm{C}$ also form moderate quantities of penicillin $\mathrm{N}$ even under optimized conditions, the ring expansion reaction might be a limiting step in cephalosporin C biosynthesis. Recently, DAOC-synthetase has been partially purified and characterized by KUPKA et al. ${ }^{5,9)}$. The enzyme was unstable and the activity was lost during further purification. The molecular weight was determined to be $31,000 \pm 3,000$ and the $\mathrm{Km}$ for penicillin $\mathrm{N}$ $0.03 \mathrm{~mm}$. Isopenicillin $\mathrm{N}$ was not accepted as a substrate. To carry out the reaction, $\alpha$-ketoglutarate and $\mathrm{FeSO}_{4}$ were required and the activity was stimulated by ascorbate and ATP. It was pointed out by KUPKA et $a l .^{5}$ that the enzyme in the biosynthetic pathway, DAOC-hydroxylase, appears to require the same cofactors and reaction conditions. In Streptomyces clavuligerus both enzyme activities were demonstrated and also their requirement for $\alpha$-ketoglutarate determined ${ }^{12,13,18)}$.

As a first step towards a more detailed understanding of the regulation of the terminal reactions in the biosynthetic pathway of cephalosporin C, a procedure was established to purify small amounts of DAOC-synthetase and hydroxylase from a high yielding mutant. Evidence was obtained that the ring expansion of penicillin $\mathrm{N}$ and the oxygenation of DAOC are catalyzed by a single dioxygenase.

\section{Materials and Methods}

Materials

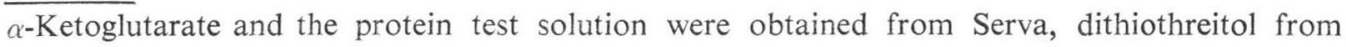


Calbiochem and ATP disodium salt from Boehringer, Mannheim. Penicillin N, isopenicillin N, DAOC and DAC were supplied by Ciba-Geigy AG.

Organism, Media and Culture Conditions

Well grown agar slant cultures of an industrial strain of Cephalosporium acremonium (synonym: Acremonium chrysogenum) TR 4 were inoculated into $100 \mathrm{ml}$ of vegetative medium $154 \mathrm{~A}$ in $500-\mathrm{ml}$ flasks. The flasks were incubated for 4 days at $25^{\circ} \mathrm{C}$ on a rotary shaker $(250 \mathrm{rpm}) . \quad 7.4$ liters of production medium ZEN 1, prepared as described below, were inoculated with $600 \mathrm{ml}$ of the 4-day old vegetative culture. The fermentation was carried out in a 14-liter laboratory fermenter (Chemap AG, Männedorf, Switzerland). The fermentation was held at a temperature of $26^{\circ} \mathrm{C}$ and an overpressure of $0.8 \mathrm{bar}$. The culture was agitated at $800 \mathrm{rpm}$ with a flat bladed turbine and the air flow rate was $1 \mathrm{vol} / \mathrm{vol} / \mathrm{minute}$. During the first 78 hours a total of $1,290 \mathrm{~g}$ glucose was fed as a $70 \%$ solution according to a preset program. From 78 hours onward soya oil was added at a rate of $1.0 \mathrm{ml} /$ liter/hour. Cells were harvested after 112 hours.

The vegetative medium 154A contained (g/liter): peptone (Difco) 10.0, malt extract (Difco) 24.0, yeast extract (Difco) $26.8, \mathrm{CaCO}_{3} 5.0$, soya oil 2.5 , tap water. The $\mathrm{pH}$ after sterilization (20 minutes, $120^{\circ} \mathrm{C}$ ) was 7.3 .

Preparation of 1 liter of fermentation medium ZEN 1: $40 \mathrm{~g}$ corn steep powder and $10 \mathrm{~g}$ peanut meal were suspended in $750 \mathrm{ml}$ tap water. The $\mathrm{pH}$ was adjusted to 6.2 . After heating for 60 minutes at $100^{\circ} \mathrm{C}$, the suspension was centrifuged for 10 minutes at $4,000 \times g$. To the supernatant, the following nutrients were added in $\mathrm{g}$ : $\left(\mathrm{NH}_{4}\right)_{2} \mathrm{SO}_{4} 12.0$, urea 3.0, $\mathrm{MgSO}_{4} \cdot 7 \mathrm{H}_{2} \mathrm{O} 7.0, \mathrm{~K}_{2} \mathrm{SO}_{4}$ 5.0, $\mathrm{CaCl}_{2} 0.3, \mathrm{FeSO}_{4}$. $7 \mathrm{H}_{2} \mathrm{O} 0.1, \mathrm{MnSO}_{4} \cdot \mathrm{H}_{2} \mathrm{O} 0.038, \mathrm{ZnSO}_{4} \cdot 7 \mathrm{H}_{2} \mathrm{O} 0.025, \mathrm{CuSO}_{4} \cdot 5 \mathrm{H}_{2} \mathrm{O} 0.025$, Cerelose 8.0 , soya oil 10.0, antifoam agent (SAG 471) 0.6, tap water. The volume was made up to 1 liter. Sterilization of the medium was carried out in the fermenter.

Preparation of Cell-free Extract

Mycelium was recovered from the fermentation broth by centrifugation and washed twice with cold deionized water. $10 \mathrm{~g}$ wet cells were suspended in $20 \mathrm{ml}$ ice-cold buffer $(0.05 \mathrm{M}$ Tris- $\mathrm{HCl}, \mathrm{pH} 8.0,0.01 \mathrm{M}$ $\left.\mathrm{KCl}, 0.01 \mathrm{M} \mathrm{MgSO}_{4}\right)$ and added to $20 \mathrm{~g}$ precooled glass beads $(\phi 0.45 \sim 0.50 \mathrm{~mm})$ in a $90-\mathrm{ml}$ glass tube. Cells were ruptured by vibrating the mixture with an immersed glass piston attached to a Vibromixer (Chemap, Typ E 1) for 1 minute (frequency $50 \mathrm{~Hz}$ ). Cell debris was removed by centrifugation at $15,000 \times g$ for 10 minutes. The supernatant was filtered successively through a $0.6 \mu \mathrm{m}$ and then a $0.2 \mu \mathrm{m}$ MF-Millipore filter. This filtrate A was stored at $-60^{\circ} \mathrm{C}$. All the operations described were carried out at $0 \sim 4^{\circ} \mathrm{C}$.

Purification of the Enzyme

Ammonium Sulfate Precipitation: The protein precipitation from filtrate A, obtained between $35 \%$ and $80 \%\left(\mathrm{NH}_{4}\right)_{2} \mathrm{SO}_{4}$ saturation, was collected by centrifugation and dissolved in buffer $\mathrm{I}(0.05 \mathrm{M}$ Tris- $\mathrm{HCl}, \mathrm{pH} 7.4,0.01 \mathrm{M} \mathrm{KCl}, 0.01 \mathrm{M} \mathrm{MgSO}_{4}$ ). This was designated enzyme solution $\mathrm{B}$.

Column Chromatography: Enzyme solution B was adsorbed on to a Sephadex G-75 column $(2.2 \times 50 \mathrm{~cm})$, equilibrated and then eluted with buffer I. The active fractions were pooled and precipitated with $80 \%\left(\mathrm{NH}_{4}\right)_{2} \mathrm{SO}_{4}$. The precipitate was collected by centrifugation and the proteins were dissolved in buffer II (0.02 M Tris- $\mathrm{HCl}, \mathrm{pH} 7.3,0.05 \mathrm{~mm}$ DAOC, $0.1 \mathrm{~mm}$ dithiothreitol). After desalting on Sephadex G-25, this solution C was chromatographed on a column $(1.5 \times 8.0 \mathrm{~cm})$ of DEAETrisacryl M, equilibrated with buffer II. Protein was eluted from the column at a flow rate of $12 \mathrm{ml} /$ hour with a linear gradient $(0.02 \sim 0.3 \mathrm{M}$ Tris- $\mathrm{HCl}$ in $120 \mathrm{ml})$ of buffer II. The most active fractions were pooled and concentrated by ultrafiltration through a DDS GR $81 \mathrm{P}$ membrane at 5 bar. This enzyme solution $\mathrm{D}$ was stored at $-60^{\circ} \mathrm{C}$.

Chromatofocusing: Enzyme solution B was loaded on to Sephadex G-25, equilibrated with buffer III (0.025 M histidine- $\mathrm{HCl}, \mathrm{pH} 6.2,0.05 \mathrm{~mm}$ DAOC, $0.1 \mathrm{~mm}$ dithiothreitol) and then eluted with the same buffer. This solution was chromatographed on a column $(1.0 \times 25.0 \mathrm{~cm})$ of polybuffer exchanger PBE 94 (Pharmacia), equilibrated with buffer III. After adsorption, the proteins were eluted at a flow rate of $17 \mathrm{ml} /$ hour with buffer IV (polybuffer 74 - $\mathrm{HCl}$ diluted with distilled $\mathrm{H}_{2} \mathrm{O}, 1:$ : , $\mathrm{pH}$ 4.0, $0.05 \mathrm{~mm}$ DAOC, $0.1 \mathrm{~mm}$ dithiothreitol). Protein peaks were monitored at $280 \mathrm{~nm}$. 
Electrofocusing: The isoelectric focusing (IEF) was performed on a cooled Pharmacia flat-bed electrofocusing unit. Enzyme solution $\mathrm{D}$ was focused in a $5 \%$ polyacrylamide gel of $0.5 \mathrm{~mm}$ thickness (LKB), containing 3\% (w/v) Ampholines, ranging from 4.0 to $6.5 \mathrm{pH}$ units. After focusing in a lengthwise direction for 3 hours at $800 \mathrm{~V}$, the band containing the enzyme activities was cut out and immediately laid on a second gel of the same kind. Focusing at $800 \mathrm{~V}$ was performed for 4 hours. Gel fragments were cut out along the $\mathrm{pH}$ gradient and eluted into buffer I overnight. This enzyme solution $\mathrm{E}$ was tested for enzyme activity. All the operations described were carried out at $4 \sim 10^{\circ} \mathrm{C}$. The gels were stained with Coomassie Brilliant Blue R-250 according to LKB instructions for analytical electrofocusing on polyacrylamide gels.

SDS-Polyacrylamide Gel Electrophoresis (PAGE): Enzyme solution E was subjected to electrophoresis under denaturing conditions, according to LAEMMLI ${ }^{17)}$. The polyacrylamide concentration was $12 \%$. After fixation the gel was stained by the Bio-Rad Silver Stain technique.

Assays

Dioxygenase: To measure DAOC-synthetase activity, a reaction mixture was prepared according to KUPKA et al.$^{9)}$ except that the penicillin $\mathrm{N}$ concentration was reduced to $0.1 \mathrm{~mm}$. The amount of protein in the test ranged from 0.05 to $0.2 \mathrm{mg} / \mathrm{ml}$, depending on the purification step. After 10 to 45 minutes, the time varying according to the enzyme activity, the reaction was stopped by adding ethanol $(1: 1)$. The precipitated proteins were removed by centrifugation and the supernatant analyzed by HPLC. DAOC-hydroxylase activity was analyzed under the same conditions as the DAOC-synthetase activity, except that DAOC was used as the substrate.

HPLC: A Zorbax BP- $\mathrm{NH}_{2}$ (Dupont) column $(4 \times 250 \mathrm{~mm})$ and a solvent system as described by Miller et al. ${ }^{19)}$ were used. The $\mathrm{pH}$ of the solvent system was adjusted to 4.0. DAOC and DAC served as standards. $50 \mu \mathrm{l}$ samples were injected and the absorption peaks were monitored at $262 \mathrm{~nm}$ (the amount of product formed was calculated with a program which integrated the area of the peaks).

Protein: Protein was determined according to BRADFORD ${ }^{19)}$. Bovine serum albumin was used as the standard.

\section{Results}

Cultivation

To facilitate separation of cells from the medium components and obtain cell extracts with high activities of the enzymes to be studied, a solid-free medium and a cultivation procedure were developed which allowed simulation of industrial production conditions on laboratory scale. In the course of the fermentation, the non-productive filamentous vegetative mycelium transformed into thick, bulging arthrospores ${ }^{20)}$. These cells which produced antibiotic at the maximum rate were harvested at 112 hours, when the cephalosporin $\mathrm{C}$ titer was about $10 \mathrm{~g} / \mathrm{liter}$.

\section{Product Analysis}

DAOC-synthetase/hydroxylase activity was determined by HPLC analysis. By selecting a $\mathrm{pH}$ of 4.0 for the elution buffer instead of 2.6 as used by MILLER et al. ${ }^{18)}$, the performance of the HPLC-system could be improved. By this means the time required to analyze a sample was reduced from 10 to 6 minutes without losing to much resolution efficiency. Incubation of penicillin $\mathrm{N}$ with crude and partially purified cell extract gave rise to two products. Their identity with DAOC and DAC was confirmed in three ways. Both products were shown to be $\beta$-lactams by their sensitivity to $\beta$-lactamase P-9921). The UV spectra obtained by UV-range scanning of the peaks and the retention times on HPLC were identical with those of the reference standards DAOC and DAC. When penicillin $\mathrm{N}$ was used as a substrate first DAOC and then DAC were formed. In the presence of higher amounts of enzyme, all the DAOC present was transformed into DAC within 20 minutes (Fig. 1). With DAOC as the substrate 
Fig. 1. HPLC chromatograms of samples taken at different reaction times.
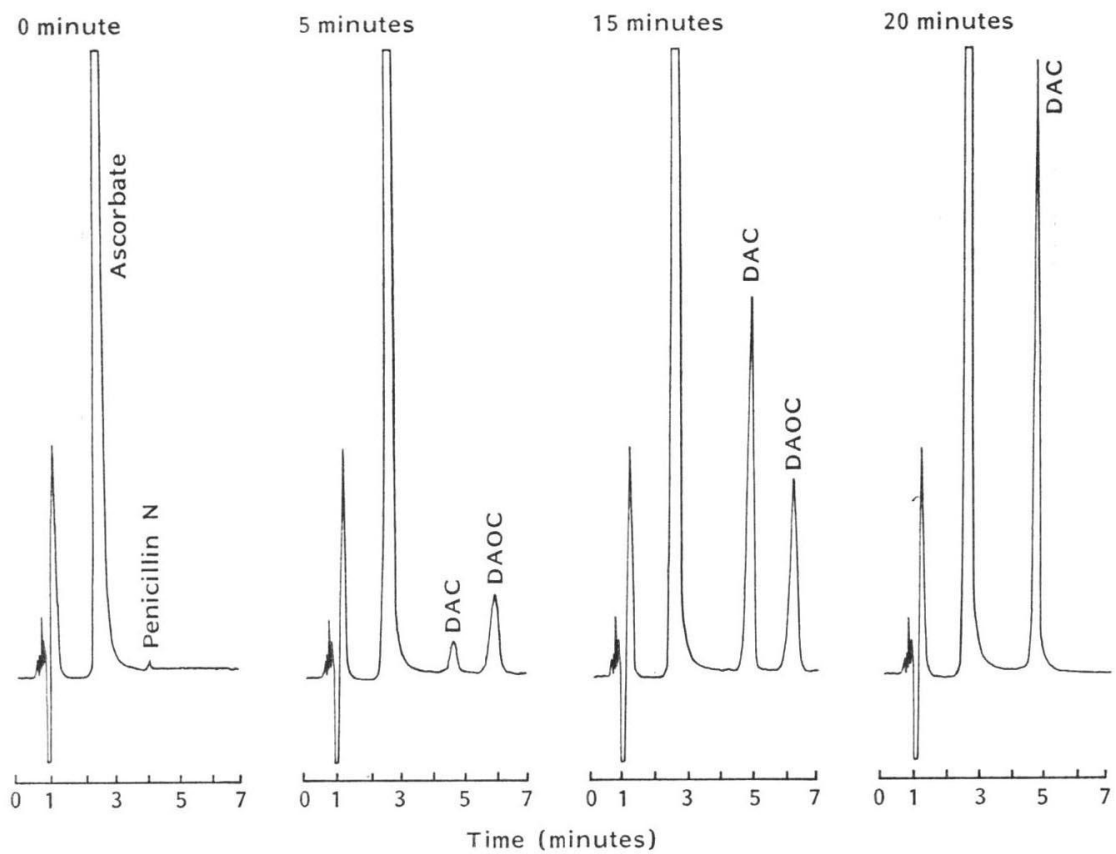

only DAC was formed.

\section{Cell Rupture and Enzyme Purification}

Since DAOC-synthetase is unstable and cell breakage by sonication gives rise to local heat production, cells were ruptured with a Vibromixer. The optimal vibration time of 1 minute led to an active enzyme extract. About $70 \%$ of the cells were destroyed without any significant $\left(<1^{\circ} \mathrm{C}\right)$ heat production.

Since purification yields of DAOC-synthetase/hydroxylase were low and could not be determined during IEF, no data on yield and degree of purification are shown. DAOC-synthetase and DAOChydroxylase activities could not be separated by means of fractional $\left(\mathrm{NH}_{4}\right)_{2} \mathrm{SO}_{4}$ precipitation and Sephadex G-75 gel chromatography. A further attempt to separate the two activities was made by using ion exchange chromatography on DEAE-Sepharose CL-6B. However, the recovery yield was too low to carry out further purification. In an attempt to improve yields the ion exchanger DEAE-Trisacryl $\mathrm{M}$ was tried. Proteins were adsorbed in $0.02 \mathrm{M}$ Tris buffer II, $\mathrm{pH} 7.3$ and eluted by increasing the buffer concentration linearily to $0.3 \mathrm{M}$. Dithiothreitol and DAOC were included in both buffers to increase stability of the enzyme. DAOC-synthetase and DAOC-hydroxylase activities eluted together shortly after the 3 main protein peaks (Fig. 2). Additional purification was obtained by IEF. Enzyme solution $\mathrm{D}$ was focused and revealed a main band at a $\mathrm{pH}$ of $4.6 \pm 0.1$, which showed activity for both reactions. Since low voltage was used to preserve the enzyme, interference from other proteins still occurred. To obtain a better separation, the proteins from the gel with the highest enzyme activities were rerun on a second gel. DAOC-synthetase and DAOC-hydroxylase activities were again present in one band at a pH of $4.6 \pm 0.1$ (Fig. 3). Additional determination of the $\mathrm{pI}$ by chromatofocusing of the enzyme solution $C$ on a polybuffer exchanger PBE 94 column gave a value of $4.5 \pm 0.1$.

The purity of the main active band after the second IEF was determined by SDS-PAGE. By the 
Fig. 2. Purification of DAOC-synthetase/hydroxylase by ion exchange chromatography on DEAE-Trisacryl M.

Formation of DAOC ( $\mathbf{m})$ by DAOC-synthetase and of DAC ( $\square$ ) by DAOC-hydroxylase. Reaction time; 35 minutes. Substrate concentration; $0.1 \mathrm{~mm}$.

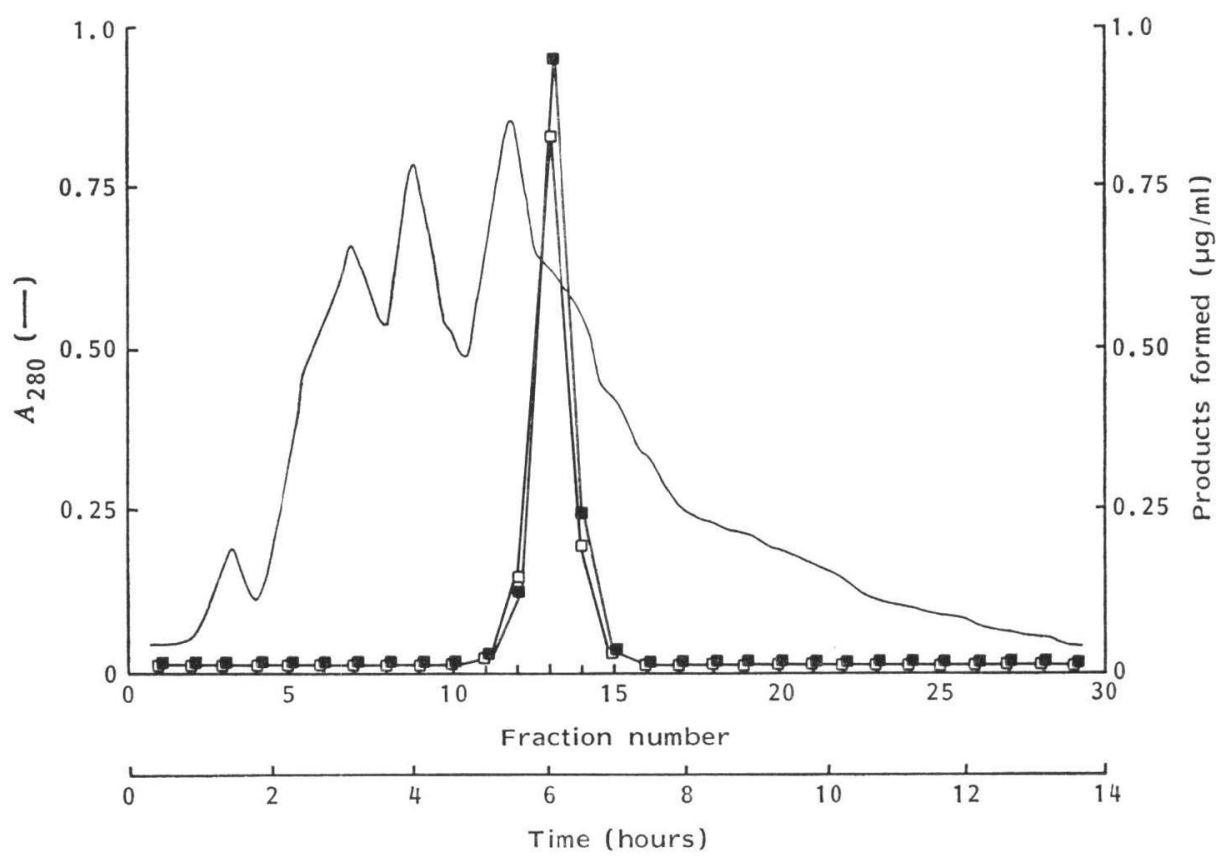

Fig. 3. Drawing of the stained polyacrylamide gel after the second focusing. DAOC-synthetase/hydroxylase activities of the cut out bands are shown.

\begin{tabular}{|c|c|c|c|c|c|}
\hline $\mathrm{pH}$ & Standard & Sample & $\begin{array}{c}\text { DAOC } \\
\text { synthetase } \\
\text { activity } \\
(\mu \mathrm{g} / \mathrm{ml})\end{array}$ & $\begin{array}{c}\text { DAOC } \\
\text { hydroxylase } \\
\text { activity } \\
(\mu \mathrm{g} / \mathrm{ml})\end{array}$ & $\begin{array}{c}\text { Fraction } \\
\text { number }\end{array}$ \\
\hline 4.4 & 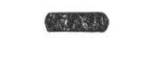 & & 0.0 & 0.0 & \\
\hline 4.6 & & & & 0.9 & 1 \\
\hline 4.8 & & 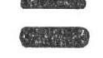 & -2.6 & 1.2 & 2 \\
\hline 5.0 & & & & 0.4 & 3 \\
\hline $\begin{array}{l}5.2 \\
5.4\end{array}$ & cand & & 0.0 & 0.0 & 4 \\
\hline
\end{tabular}

sensitive silver stain technique several bands could be detected (Fig. 4). The only one which correlated with both enzyme activities (determined after second IEF) was at a molecular weight of $33,000 \pm 2,000$. In the fractions, where this main band was lacking, no activity could be found. Based on this finding we conclude tentatively that the ring expansion of penicillin $\mathrm{N}$ and the oxygenation of DAOC are catalyzed by the same enzyme. 
Fig. 4. SDS-PAGE of the active band and adjacent areas after second IEF. Activities were determined after the second IEF.

\begin{tabular}{|c|c|c|c|c|c|c|}
\hline \multirow{2}{*}{ Molecular weight } & \multicolumn{6}{|c|}{ Fraction number } \\
\hline & 1 & 2 & Standard & 3 & 4 & 5 \\
\hline \multicolumn{7}{|l|}{43,000} \\
\hline \multicolumn{7}{|l|}{30,000} \\
\hline \multicolumn{7}{|l|}{20,100} \\
\hline $\begin{array}{l}\text { DAOC synthetase } \\
\text { activity }(\mu \mathrm{g} / \mathrm{ml})\end{array}$ & 1.1 & 2.6 & & 0.5 & 0 & 0 \\
\hline $\begin{array}{c}\text { DAOC hydroxylase } \\
\text { activity }(\mu \mathrm{g} / \mathrm{ml})\end{array}$ & 0.9 & 1.2 & & 0.4 & 0 & 0 \\
\hline
\end{tabular}

Fig. 5. Time slope of product formation of DAOCsynthetase/hydroxylase.

(圈) DAOC-synthetase activity. ( $\square$ ) DAOChydroxylase activity.

Protein concentration; $0.4 \mathrm{mg} / \mathrm{ml}$.

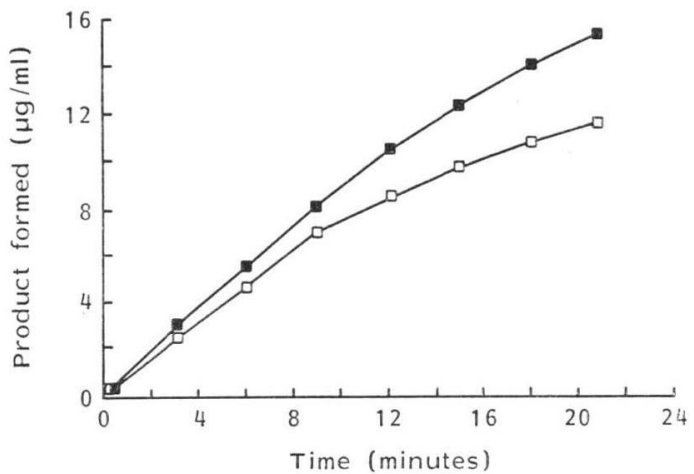

Fig. 6. Effect of $\alpha$-ketoglutarate on DAOC-synthetase activity (줌) and DAOC-hydroxylase activity $(\square)$.

Substrate concentration; $0.1 \mathrm{~mm}$. Protein concentration; $0.4 \mathrm{mg} / \mathrm{ml}$, reaction time; 10 minutes.

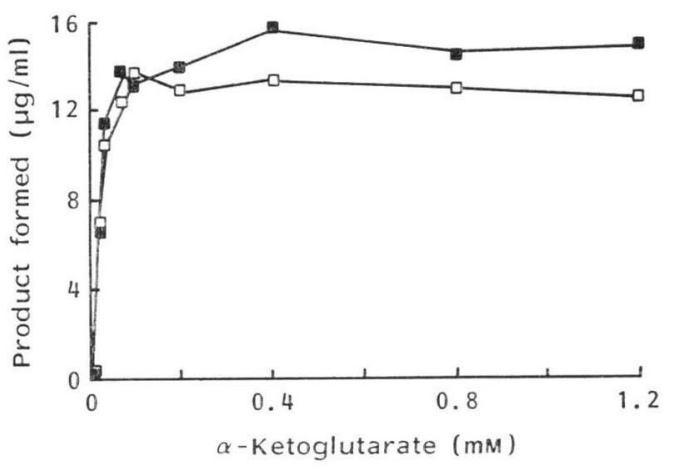

\section{Catalytic Properties}

Cofactor dependence and oxygen requirement were determined for the first time under identical test conditions for both reactions, ring expansion and oxygenation. Since only a small amount of enzyme was available after ion exchange chromatography and IEF, the catalytic properties of DAOC-synthetase/hydroxylase had to be determined with enzyme solution C. Reaction times of less than 10 minutes were chosen because the reaction rate after 10 minutes ceased to be linear with time (Fig. 5). Preincubation of the reaction mixture without substrate, as described by TURNER et al. ${ }^{12)}$, did not further 
Fig. 7. Effect of $\mathrm{FeSO}_{4}$ on DAOC-synthetase activity (四) and DAOC-hydroxylase activity $(\square)$.

Substrate concentration; $0.1 \mathrm{~mm}$. Protein concentration; $0.4 \mathrm{mg} / \mathrm{ml}$, reaction time; 10 minutes.

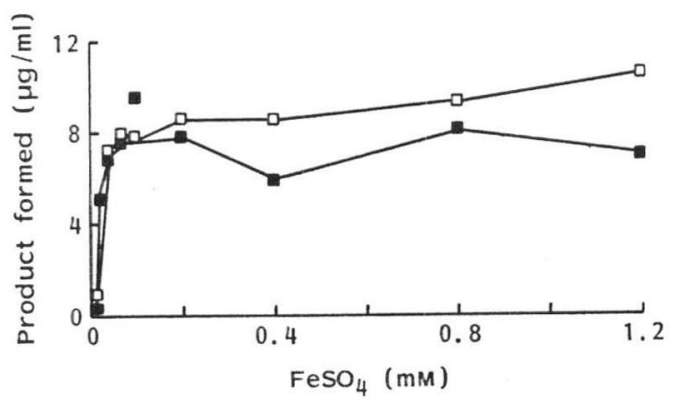

Fig. 9. Effect of ATP on DAOC-synthetase activity (a) and DAOC-hydroxylase activity ( $\square$ ).

Substrate concentration; $0.1 \mathrm{~mm}$. Protein concentration; $0.4 \mathrm{mg} / \mathrm{ml}$, reaction time; 10 minutes.

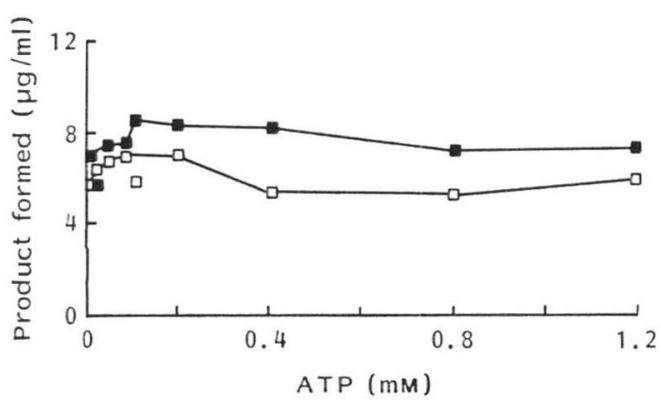

Fig. 8. Effect of ascorbate on DAOC-synthetase activity () and DAOC-hydroxylase activity ( $\square$ ).

Substrate concentration; $0.1 \mathrm{~mm}$. Protein concentration; $0.4 \mathrm{mg} / \mathrm{ml}$, reaction time; 10 minutes.

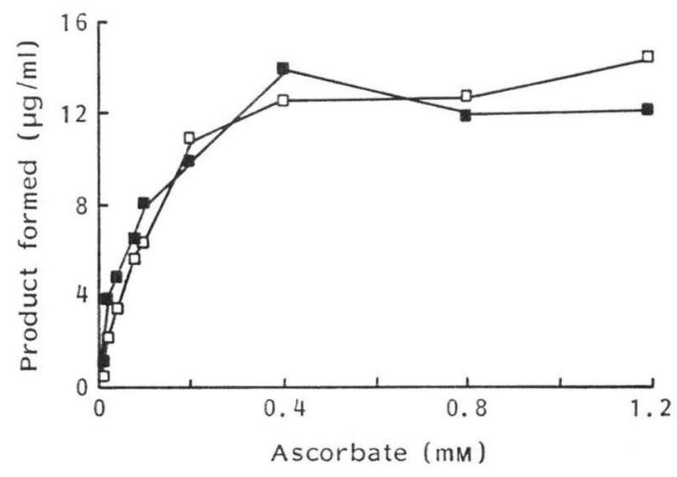

stimulate the reaction. The reason for this difference in findings is not known but it may be due to another enzyme purification procedure. The demand of both reactions for $\alpha$-ketoglutarate and $\mathrm{FeSO}_{4}$ is shown in Figs. 6 and 7. By omitting these two cofactors, no products were formed. The simultaneous dependence on $\alpha$-ketoglutarate and $\mathrm{FeSO}_{4}$ supports the hypothesis mentioned by $\mathrm{WALSH}^{22)}$ that an enzyme bound persuccinate intermediate is formed from an enzyme-Fe- $\mathrm{O}_{2}-\alpha-$

ketoglutarate complex. Ascorbate, which is thought to reduce $\mathrm{Fe}^{3+}$, is required for both activities (Fig. 8), whereas the addition of ATP shows only a slight stimulation of about 20 25\% (Fig. 9). From several experiments a $K m$ of $0.03 \mathrm{~mm}$ for penicillin $\mathrm{N}$ and of $0.02 \mathrm{~mm}$ for DAOC were obtained. When isopenicillin $\mathrm{N}$ was added as substrate to the IEF purified enzyme solution it was not converted to a cephalosporin.

\section{Discussion}

A characteristic of the DAOC-synthetase/hydroxylase is its instability during purification. When purifying DAOC-synthetase, KUPKA et al. ${ }^{9)}$ also observed a pronounced instability. Since alternative purification methods such as chromatofocusing, fast protein liquid chromatography and affinity chromatography on Sepharose linked $\alpha$-ketoglutarate did not result in a significant improvement and no sufficiently good stabilizing agent was found, it was necessary to forego the final preparative purification and to work with a partially purified enzyme.

The purest active preparation obtained after repeated IEF contained mainly 3 bands on SDS-gel, 2 of which were also present in neighboring inactive fractions. Thus, the DAOC-synthetase/hydroxylase activities can most probably be attributed to a protein migrating as a single band in a SDS-gel and having a molecular weight of $c a .33,000$. This molecular weight is in agreement with the value estimated by KUPKA et al.$^{9)}$ for the DAOC-synthetase. Further indirect evidence in support of our conclusion that one enzyme catalyzes the ring expansion and oxygenation reactions is given by the following observations. At no point during the many different purification experiments was it possible to detect any 
sign of separation of the two activities. The requirements for the cofactors $\alpha$-ketoglutarate, $\mathrm{FeSO}_{4}$ and ascorbate are virtually identical for both reactions. To our knowledge, extensive screening for DAOC overproducing C. acremonium mutants has not led to the discovery of strains with a block at the oxygenation step. The DAOC mutants described by FuJISAWA et al. ${ }^{23)}$ and QUeENER et al. ${ }^{24)}$ still produced considerable amounts of DAC. The same holds true for the mutants isolated in our laboratory. LIERSCH et al. ${ }^{15)}$ did in fact describe a mutant that only produced DAOC, but after testing the productivity of this strain in later years using a more sophisticated HPLC test system, the mutant was also shown to produce DAC and cephalosporin C. If ring expansion and oxygenation were to be catalyzed by two separate enzymes, one would expect it to be much easier to find a mutant blocked for only one of the enzymes. The cofactor requirements are typical for a dioxygenase and are in good agreement with what has been described so far in the literature ${ }^{5,10,12)}$ for the single activities. The only exception is the absence of a strong positive effect of ATP addition. Therefore, one cannot be sure if ATP is strictly necessary for these enzyme reactions, although it does have a slight stimulatory effect. However, it is possible that enzyme bound ATP assists in the two oxygenations which would then explain the minimal effect of additional ATP.

Although the net result of the ring expansion reaction shows no incorporation of oxygen, the actual mechanism may involve an oxygenation of penicillin $\mathrm{N}$ to its sulfoxide ${ }^{25,28)}$. This may bring about the opening of the ring structure followed by closure to the six-membered ring and concomitant release of the hydroxyl group. If this assumed mechanism were true both the ring expansion and the oxygenation reactions could be considered as oxygenations involving the most reactive group present in the substrate molecule. The specificity of the enzyme seems to be directed more towards the side chain than to the $\beta$-lactam nucleus. The L-configuration of the $\alpha$-aminoadipic acid moiety of isopenicillin $\mathrm{N}$ prevents ring expansion. An interesting reaction in which oxygenation was also observed, was recently described by AdLington et al. ${ }^{27}$. A crude extract of C. acremonium mycelium catalyzed the conversion of 3exomethylene cephalosporin C to DAC. No formation of DAOC as an intermediate was observed. Direct hydroxylation to DAC by the same enzyme as that which converts penicillin $\mathrm{N}$ to DAOC and DAOC to DAC may occur. Support for this hypothesis is given by the fact that no 3-exomethylene cephalosporin $\mathrm{C}$ could be found in C. acremonium.

There is now sufficient scientific data on DAOC-synthetase/hydroxylase to conclude that different control mechanisms are responsible for the amount of enzyme produced and its activity during the course of the fermentation. A high glucose level in the fermentation medium (6\%) strongly represses ring expansion activity, but cyclization and subsequently penicillin $\mathrm{N}$ production is only slightly repressed ${ }^{28 \sim 31}$. The decreased activity of the oxygen dependent DAOC-synthetase/hydroxylase might be also due to an intracellular oxygen deficiency, since in the presence of large amounts of glucose, the oxygen requirements for glycolysis and respiration are high. This would agree with our finding that DAOC-synthetase/ hydroxylase activities can be strongly inhibited in vitro by excluding oxygen. A more thorough understanding of the factors governing synthesis and activity of the two enzymes DAOC-synthetase/hydroxylase and DAC-acetylase is necessary. High activities of both enzymes are a prerequisite to prevent excretion of cephalosporin $\mathrm{C}$ precursors and to ensure maximal cephalosporin $\mathrm{C}$ productivity.

\section{Acknowledgments}

We thank H. H. Peter for supplying penicillin N and isopenicillin N, J. KONECNY for his counsel, T. KuHN for assistance with HPLC, D. M. FAupel for his help with IEF and J.A.L. Auden, A. SMith and J. KupKa for reviewing the manuscript.

\section{References}

1) Lara, F.; R. D. C. Mateos, G. Vázquez \& S. Sánchez: Induction of penicillin biosynthesis by L-glutamate in Penicillium chrysogenum. Biochem. Biophys. Res. Commun. 105: 172 178, 1982

2) Abraham, E. P.; J. A. Huddlestone, G. S. Jayatilake, J. O’Sullivan \& R. L. White: Conversion of $\delta$ (L- $\alpha$-aminoadipyl)-L-cysteinyl-D-valine to isopenicillin $\mathrm{N}$ in cell-free extracts of Cephalosporium acremonium. Spec. Publ. No. 38, Proceed. Sec. Int. Symp., Ed. G. I. GreGory, pp. $125 \sim 134$, England, 1980 
3) Sawada, Y.; J. E. Baldwin, P. D. Singh, N. A. Solomon \& A. L. Demain: Cell-free cyclization of $\delta$ (L- $\alpha$-aminoadipyl)-L-cysteinyl-D-valine to isopenicillin N. Antimicrob. Agents Chemother. 18: 465 470, 1980

4) Baldwin, J. E.; B. Chakravarti, L. D. Field, J. A. Murphy \& K. R. Whitten: The synthesis of L- $\alpha$ aminoadipyl-L-cysteinyl-D-3,4-di-dehydrovaline, a potent inhibitor of isopenicillin synthetase. Tetrahedron 38: $2773 \sim 2776,1982$

5) Kupka, J.; Y.-Q. Shen, S. Wolfe \& A. L. Demain: Studies on ring-cyclization and ring-expansion enzyme of $\beta$-lactam biosynthesis in Cephalosporium acremonium. Can. J. Microbiol. 29: 488 496, 1983

6) Konomi, T.; S. Herchen, J. E. Baldwin, M. Yoshida, N. A. Hunt \& A. L. Demain: Cell-free conversion of $\delta$-(L- $\alpha$-aminoadipyl)-L-cysteinyl-D-valine into an antibiotic with the properties of isopenicillin $\mathrm{N}$ in Cephalosporium acremonium. Biochem. J. 184: 427 430, 1979

7) Jayatilake, G. S.; J. A. Huddleston \& E. P. Abraham: Conversion of isopenicillin $\mathrm{N}$ into penicillin N in cell-free extracts of Cephalosporium acremonium. Biochem. J. 194: 645 647, 1981

8) Baldwin, J. E.; J. W. Keeping, P. D. Singh \& L. A. Vallejo: Cell-free conversion of isopenicillin N into deacetoxycephalosporin C by Cephalosporium acremonium mutant M-0198. Biochem. J. 194: 649 651, 1981

9) Kupka, J.; Y.-Q. Shen, S. Wolfe \& A. L. Demain: Partial purification and properties of the $\alpha$-ketoglutarate-linked ring-expansion enzyme of $\beta$-lactam biosynthesis of Cephalosporium acremonium. FEMS Microbiol. Lett. 16: 1 6, 1983

10) Baldwin, J. E.; P. D. Singh, M. Yoshida, Y. Sawada \& A. L. Demain: Incorporation of ${ }^{3} \mathrm{H}$ and ${ }^{14} \mathrm{C}$ from $\left[6-{ }^{3} \mathrm{H}\right]$ penicillin $\mathrm{N}$ and $\left[10-{ }^{14} \mathrm{C}, 6-{ }^{3} \mathrm{H}\right]$ penicillin $\mathrm{N}$ into deacetoxycephalosporin C. Biochem. J. 186: 889 895, 1980

11) Felix, H. R.; H. H. Peter \& H. J. Treichler: Microbiological ring-expansion of penicillin N. J. Antibiotics 34: $567 \sim 575,1981$

12) Turner, M. K.; J. E. Farthing \& S. J. Brewer: The oxygenation of $\left[3-m e t h y l-{ }^{3}\right.$ H]desacetoxycephalosporin C [7 $\beta$-(5-D-aminoadipamido)-3-methylceph-3-em-4-carboxylic acid] to [3-hydroxymethyl- $\left.{ }^{3} \mathrm{H}\right] \mathrm{des}$ cephalosporin C by 2-oxoglutarate-linked dioxygenases from Acremonium chrysogenum and Streptomyces clavuligerus. Biochem. J. 173: 839 850, 1978

13) Brewer, S. J.; J. E. FARThIng \& M. K. TURner: The oxygenation of the 3-methyl group of 7, $3-(5-\mathrm{D}-$ aminoadipamido)-3-methylceph-3-em-4-carboxylic acid (desacetoxycephalosporin C) by extracts of Acremonium chrysogenum. 569th Meeting Biochem. Soc. Transact., Vol. 5, pp. 1024 1029, Sussex, 1977

14) Fujisawa, Y. \& T. Kanzaki: Role of acetyl CoA: Deacetylcephalosporin C acetyltransferase in cephalosporin C biosynthesis by Cephalosporium acremonium. Agric. Biol. Chem. 39: 2043 2048, 1975

15) Liersch, M.; J. Nüesch \& H. J. Treichler: Final steps in the biosynthesis of cephalosporin C. 2nd Int. Symp. Genet. Ind. Microorg., Ed., K. D. MaCdonald, pp. 179 195, Acad. Press, London, 1976

16) Jensen, S. E.; D. W. S. Westlake, R. J. Bowers \& S. Wolfe: Cephalosporin formation by cell-free extracts from Streptomyces clavuligerus. J. Antibiotics 35: 1351 1360, 1982

17) Laemml, U. K.: Cleavage of structural proteins during the assembly of the head of bacteriophage T4. Nature 227: 680 685, 1970

18) Miller, R. D.; L. L. Huckstep, J. P. McDermott, S. W. Queener, S. Kukolja, D. O. Spry, T. K. Elzey, S. M. LAwrence \& N. Neuss: High performance liquid chromatography (HPLC) of natural products. IV. The use of HPLC in biosynthetic studies of cephalosporin C in the cell-free system. J. Antibiotics 34: $984 \sim 993,1981$

19) BRADFORD, M. M.: A rapid and sensitive method for the quantitation of microgram quantities of protein utilizing the principle of protein-dye binding. Anal. Biochem. 72: 248 254, 1976

20) NAsh, C. H. \& F. M. Huber: Antibiotic synthesis and morphological differentiation of Cephalosporium acremonium. Appl. Microbiol. 22: 6 10, 1971

21) Konecny, J. \& A. Schneider: Alkalimetric microassay of cephalosporins. J. Antibiotics 31: 776 782, 1978

22) Walsh, C.: Dioxygenases requiring an $\alpha$-keto-acid cosubstrate. In Enzymatic Reaction Mechanisms. pp. $501 \sim 510$, W. H. Freeman \& Co., San Francisco, 1979

23) Fujisawa, Y.; K. Kitano \& T. Kanzaki: Accumulation of deacetoxycephalosporin C by a deacetylcephalosporin C negative mutant of Cephalosporium acremonium. Agric. Biol. Chem. 39: 2049 2055, 1975

24) Queener, S. W. \& J. J. CAPOnE: Deacetoxycephalosporin C accumulation in mutants of Cephalosporium acremonium. Abstract 2nd Int. Symp. Genet. Ind. Microorg., p. 33, 1974

25) Morin, R. B.; B. G. Jackson, R. A. Mueller, E. R. Lavagnino, W. B. Scanlon \& S. C. Andrews: 
Chemistry of cephalosporin antibiotics. III. Chemical correlation of penicillin and cephalosporin antibiotics. J. Am. Chem. Soc. 85: 1896 1897, 1963

26) COOPER, R. D. G. \& F. L. JosÉ: Structural studies on penicillin derivatives. IX. Synthesis of thiazolidineazetidinones. J. Am. Chem. Soc. 94: 1021 1022, 1972

27) Adlington, R. M.; J. E. Baldwin, B. Chakravarti, M. Jung, S. E. Moroney, J. A. Murphy, P. D. Singh, J. J. Usher \& C. VAllejo: Conversion of 3-exomethylene cephalosporin C into deacetylcephalosporin C in a cell-free extract from Cephalosporium acremonium (CW-19). J. Chem. Soc., Chem. Commun. 1983: 153 154, 1983

28) KÜENZI, M. T.: Regulation of cephalosporin synthesis in Cephalosporium acremonium by phosphate and glucose. Arch. Microbiol. 128: 78 83, 1980

29) ZANCA, D. M. \& J. F. MARTíN: Carbon catabolite regulation of the conversion of penicillin N into cephalosporin C. J. Antibiotics 36: 700 708, 1983

30) Behmer, C. J. \& A. L. Demain: Further studies on carbon catabolite regulation of $\beta$-lactam antibiotic synthesis in Cephalosporium acremonium. Curr. Microbiol. 8: 107 114, 1983

31) Shen, Y. Q.; J. KuPKA \& A. L. Demain: Regulation of $\beta$-lactam-synthetase activity during the fermentation of Cephalosporium acremonium. Abstract Ann. Meeting Am. Soc. Microbiol., p. 200, Atlanta, 1982 